\title{
The path analysis on university clean and honest culture from the perspective of the new era
}

\author{
Yuming Zhang \\ Commission of discipline of the China West Normal University, Nanchong 637009, China \\ zhangyuming_160@163.com
}

Keywords: The new era, clean culture, cultural path.

\begin{abstract}
To strengthen the construction of clean culture in colleges and universities, which is the need of inheriting Chinese traditional culture, and is the need of creating the atmosphere of clean air in the campus and the training of talents in colleges and universities. Universities should overcome all kinds of problems in the construction of clean government and culture, and to explore new ways of building a new public integrity path under the new era, to ensure that the integrity of the cultural construction, to create a culture of public integrity and a new environment.
\end{abstract}

\section{Introduction}

The campus integrity culture is an important part of the integrity construction of colleges and universities, as well as an important part of campus culture. As the state continues to strengthen the construction of the Party's clean government, integrate the construction of the clean government culture into the whole process of the construction and development of colleges and universities, focus on the cultivation of clean value concept, conduct a wide range of activities of the anti-corruption culture, and vigorously create the non-corrupt campus fashion, provide ideological and cultural support for the in-depth development of the party's clean government construction and the fight against corruption.

\section{Colleges and universities enhance the value of clean culture construction}

\subsection{Strengthening honest culture is the need of inheriting Chinese traditional culture}

The clean culture of China is the summation of the culture of honesty, theory, belief and adaptation to the form of expression, code of conduct, value orientation and relationship, which is the core element of the Chinese excellent traditional culture, is the important content of socialist advanced culture, clean and honest culture as the main part of Chinese traditional culture, in the long history of change the thought and behavior of people In the modern age, high schools are important positions of human culture, college students are the main force of the traditional culture, strengthening the culture of public integrity is to inherit and carry forward Chinese traditional culture.

\subsection{Honest cultural construction is the need of clear campus atmosphere}

Universities are the holy halls of talent cultivation. As an important content of university cultural construction, clean culture plays an important role in stimulating, standardizing, guiding and teaching, affecting the value orientation and behavior of people. universities will integrate clean culture into education teaching, which can cultivate students' integrity consciousness and form correct values of integrity. To integrate the clean culture into the construction of teachers, to uphold honesty and education, and to be a role model for teaching and educating people; To integrate the clean culture into the building of the leadership, to keep the integrity of the administration, to make sure that the efficiency of the right to run the transparency, in any case, the culture of public integrity, as a healthy, uplifting campus culture, is to be able to cope with the unhealthy ethos of the campus, to resist the erosion of all kinds of decadent ideas, and to create the new atmosphere

\subsection{The construction of clean culture is the need of talents training in colleges}

The campus culture can equip people, guide people, mold people, education people and cultivate people, Through the legacy of culture, dissemination and creation, promoting the socialization, 
individuality and civilization of the educated people, which shape the person who has the integrity and the perfection of the personality, and realize the process of continuous development beyond the university students themselves and to carry out the anti-corruption education to college students, to strengthen the ideal belief, values, moral cultivation and integrity of education, to help college students establish the correct values of integrity, and lay the ideological foundation for "clean employment" in the future.

\section{The problems existing in the construction of college campus integrity culture}

\subsection{Some universities don't pay enough attention to the university's public integrity}

For colleges and universities, the focus is more on professional development, curriculum construction and social services. It is good for the construction of a clean government culture, but no real thought has been made on how to plan and deploy the clean culture as part of campus culture. From the school level, some leaders have not really assumed the main responsibility of the Party's clean and clean government construction, and believe that it is the matter of the discipline inspection department. Some departments think that the construction of a clean government culture is a metaphysical thing and the design of a shelf; The supervision and responsibility of discipline inspection supervision department shall be responsible for the positioning of a education material, appropriate supervision over some work and investigation of some work as necessary, so as to ensure that there is less deep thought on the cultural construction of honest. It can lead to that construction of the culture of the honest culture of high learning, which can only be work on the surface, and cannot be systematically designed and advanced.

\subsection{In the process of college campus honest cultural construction, common weighs cadres' problem between teachers and students}

Only focusing on the anti-corruption campaign and the public service, but ignoring the education for the teachers and students. Teachers in colleges and universities are responsible for the task of "preaching, teaching and solving" and the words and actions of teachers influence students in subtle ways, some of the teachers in the class are expressing their anger towards society and the vague awareness of the Chinese characteristics of socialism that has a profound effect on college students who are in the process of establishing a period of values; In addition, it is some college teachers, especially as a tutor and a mentor of major projects, to students in the process of apply for funding to help to collect all kinds of tickets, in the process of supervision for cheating students ignore behavior, etc.in the act virtually also took root in students mind to student's values,. College education is the key to a college student who can be a builder and a reliable candidate for socialism. Some students join the communist Party of China for utilitarian purposes, join the school students' union, society organizations, to increase the clean education for these students, from the student period, the seeds of the right of incorruptibility in their minds, which are more conducive to the students to establish the correct world view, outlook on life, values and power view.

\subsection{Education form is single and lacks pertinence}

At present, most colleges and universities have not been able to set up an independent clean education content according to the diversity of education object of the honest government culture, leading to education content is single and lacks pertinence. The effect of education is not obvious. some colleges and universities in the construction of clean government, regardless of the main, the object, take the form of a one-size-fits-all, to the university leadership cadre, the teacher, the student unite to carry on education and the related training, resulting in "eyebrow beard a grab", the effect is not obvious.some cadres don't recognize the change in the current environment, and it is considered that the teachers of high school are not involved in the work of public integrity, and just do the teaching job,no targeted clean education content for teachers; fact that some cadre believe that students of high school are still children, they are unable to reach a substantial right and do not need to conduct the education so as to result in ineffective culture of honest government. 


\subsection{Education content pertinence is not strong}

The education is lacking in rich supports and forms single in some colleges and universities.some universities cannot combine the construction of anti-corruption culture with college students' study and life in the process of carrying out the construction of honest government culture, and education is only limited in the form of meetings,presentation, lectures and other forms. It ignores the integration of the cultural construction and the university's strategic development, school spirit and school culture cannot use the campus radio, school newspaper, publicity column, official micro-blog and We-chat and other public media, Generally exists in some universities for college students cheating in their stead, examination, assessment awards party bribery counselors, coursework plagiarism, graduation thesis fraud and other issues, not the first time, targeted to carry out the education of honesty and integrity of ideological education, cause the effect of the college students' integrity, culture education.Some colleges have no infiltration of education activities, which are often superficial and hard to be effective. The essence of the construction of clean government culture is to cultivate people's outlook on life and value, which is "proud of being honest and greedy for corruption", while some colleges and universities are putting the cart before the horse. The purpose of building a clean government and cultural construction is to expand the education place, beautify the education landscape, and establish the education system and the external culture of the institution. it is the fundamental purpose of the construction of the integrity of the university campus to promote the correct concept of integrity and the awareness of integrity.

\section{The university carries out the path of building a clean government culture}

\subsection{To strengthen the integrity of college students' values incubation}

To closely around the central task of the teaching of colleges and universities, give full play to the talent advantage and resource advantage, the content of the scientific and reasonable to build the honest cultural construction, the honest cultural construction is embodied in all aspects of education, from every link of the consolidation of education and college students' professional course study, the ideological and political education, career planning education and school education school rules, into students' mind, value concept will be clean in heart, externalized in line, form the correct values of integrity, to strengthen the construction of university clean and honest culture in college students' honesty cognition.

\subsection{Innovative public cultural construction vehicles}

the university's culture of public integrity, as an important part of campus culture, should be able to use the advantages of the various carriers, and build a rich culture of public culture. Make full use of the advantages of education of good university culture, and use the form of calligraphy exhibition, report meeting, speech contest, special lectures, honest works to collect, send honest text message, read the clean government book and other forms, and give full play to the guiding, inspiring and cohesive function of excellent works, and provide a richer cultural support for the construction of anti-corruption.

\subsection{Building a public integrity education platform}

One is the honest cultural construction should be brought into the teaching plan, in the ideological and political theory course teaching into honest knowledge actively, giving full play to the role of main channel of ideological and political theory course, and using a variety of the compulsory courses and elective courses, joining the honesty education section in the content, The second is to set up the second class of a clean education class, like a Party class, a group class, a job coaching class, and a law and education class, to get a clean education from the daily life of a college student; third, colleges and universities should set about building an anti-corruption culture club, conduct clean education learning and practice activities through the guidance of the relevant departments of the discipline inspection commission, the social science department and the youth league committee, and build a clean education communication platform, strengthen the integrity, the radial force of culture. 


\subsection{Developing an Internet integrity culture}

The network is the new media,which has the great advantage of wide dissemination, strong interactivity, real-time, flexible, and low cost and so on. With the rapid development of the Internet, human society has entered an unprecedented network era. Which has caused the network culture to break the traditional framework and has exerted a great influence on the integrity culture, which has gradually infiltrated and integrated into the network culture. In recent years, the enthusiasm of Chinese citizens' online political participation has also increased, and they have made full use of the Internet to participate in political and political affairs, democratic supervision and expression of appeals. network culture is both a blessing and a curse, however, the network at the same time of actively promote honest cultural construction, also can bring the rumor, Internet fraud, network spread violence, pornography, adverse effects. Therefore, it is of great practical significance to actively use the clean culture to take over the network positions and use the Internet to build a clean government culture.

\section{References}

[1] Xiaowen Wei, Zhichuang Tian. The new era of public integrity and cultural construction[J]. Thought theory education, 2012, (11)

[2] Qi Zhang,Research on the construction mechanism of the clean culture in colleges and universities [J]. China power education, 2010, (19) 